\title{
Life Course
}

\section{Johannes Huinink and Betina Hollstein}

\begin{abstract}
Research into individual life courses can be considered a special means of investigating social change. This chapter reviews contributions to life-course research in German-language sociology with a focus on its development over the last two decades. We start with a brief overview of the early years of life-course research and sketch three strands of research that were original even by international standards. In the second section, we describe conceptual and methodical approaches to Germanlanguage life-course research along with important data collections that triggered a plethora of empirical life-course studies. Section three focuses on the primary fields of life-course research and provides examples of empirical contributions by quantitative studies. In section four, we address specific characteristics of biographical research in German-speaking countries that can fertilize life-course research. The chapter closes with some brief remarks about the challenges that life-course research faces in the future.
\end{abstract}

Keywords: Life course, biography, life history

About fifty years ago, various comprehensive approaches to a "life-course perspective" in sociology were developed. These built on a long history of social research on individual lives and biographies. A major motivation in this effort was to achieve a better understanding of the rapid social change in Western societies by investigating the relationship between changing patterns of individual lives and their societal environment. The conceptual efforts to establish a differentiated agenda of life-course research have been paralleled by the steady development of refined quantitative and qualitative methods of collecting and analyzing life-course data in social research (cf. Elder and Giele, 2009; Mayer, 2004; 2009). These efforts have yielded advances in longitudinal research not only on the macro but also on the micro level.

\section{Early Life-Course Research in German-Language Sociology}

In German-language sociology, the life-course approach was introduced in the late 1970s, and the work of German-speaking scholars in this field has gained recognition internationally ever since. As part of the German Science Foundation's Collaborative Research Centre (CRC) 3, "Microanalytic Foundations of Social Policy," Karl Ulrich

Note: We draw selectively upon Hollstein (2019) in sections four and five. 
Mayer and his colleagues founded a quantitative research program ("German Life History Study") that established and made use of a rich collection of quantitative retrospective life-course data at the Max Planck Institute of Human Development in Berlin (Mayer, 1990). At the Free University in Berlin, Martin Kohli published an early edited volume that introduced the life-course approach to German-language sociology (Kohli, 1978). In his own research, he studied the emergence of the "institutionalization of the modern life course" as a secular trend over the previous two centuries (Kohli, 1985). Together with his colleagues, he started a research program that collected and utilized primarily qualitative, biographical data on individual life courses. In the 1990s at the University of Bremen, the German Science Foundation's CRC 186, "Status Passages and Risks in the Life Course," integrated different approaches to the life-course perspective and primarily studied the impact of social policy, social institutions, and socio-psychological issues on the life course (Heinz et al., 2001). In the following, we will provide a short overview of how some of the aspects in these three strands developed as part of German-language life-course research-developments that were also original by international standards.

From a theoretical standpoint, German-language life-course research put a strong emphasis on the role of social structure and social institutions. Mayer and his team considered particular life-course regimes to be shaped by the social structure of a society (e.g., the labor market, education, social inequality) that itself is steadily changing as a result of the aggregated outcomes of individual life courses (Mayer and Blossfeld, 1990; Huinink, 1995; Huinink et al., 1995; Mayer, 2004). Another major force structuring the life course is the state (Mayer and Müller, 1986). With that in mind, life courses were conceptualized as complex, multidimensional, and "self-referential process[es]” with “endogenous causation” (Mayer and Huinink, 1990; Mayer, 2004: 166). Kohli considered the modern life course to be shaped by an interplay between modern institutions and the subjective construction of a coherent biography and to be structured by institutions that have evolved over the course of societal modernization and by a trend toward increasing individualization (in a relationship of mutual augmentation, or Steigerungsverhältnis). The tripartite life course itself could be perceived as an institution, that is to say, a normative sequence of phases (periods of preparation, "activity," and retirement) that individuals typically go through during their lifetime. This institutional script was expected to undergo a future process of de-institutionalization in the wake of the assumed erosion of modern institutions. (Kohli, 1985; 1988; 2007). The Bremen CRC "Status Passages and Risks in the Life Course," which was launched in 1988, produced new insight into the dynamics and societal conditions of major transitions in the life course (status passages, or Statuspassagen) by studying institutional and social influences with an emphasis on social policy and life-course policy (Leisering and Leibfried, 1999; Leisering, 2004; Weymann, 1996; 2004) as well as gendered life courses that follow gender-sensitive institutional pathways or arrangements (Krüger and Levy, 2001). Another aspect that has been emphasized is the role of personal agency and individual decisions in weakening the institutional structuration of individual life courses as part of the process of social 
change. Noteworthy attempts have been made to fuse methodological concepts from sociology (the life course) with psychological concepts (the lifespan) and to combine quantitative with qualitative methods of analysis. This has strengthened the link to developmental and social psychology-already quite prominent in life-course research in the United States (Heinz, 2002; Diewald and Mayer, 2009).

Methodologically speaking, the German-language life-course tradition fertilized research in two different directions: a quantitative, socio-structural analysis of the life course and a qualitative, biographical analysis of the life course. Researchers in Mayer's group were among the pioneers in developing the quantitative approach of retrospective data collection (Brückner and Mayer, 1998) and longitudinal analysis of individual life courses in modern societies. These included event-history analysis (Blossfeld et al., 1989) and complementing macro-level, demographic cohort analysis with complex multi-level longitudinal designs (Blossfeld, 1989; Mayer and Huinink, 1990). Kohli and his group initiated a "German tradition" of qualitative biographical analysis, which they and others have elaborated into a unique biographical approach of analyzing individual narrative recordings (Bertaux and Kohli, 1984; Schütze, 1983; 2008; Rosenthal, 1993). Also worth mentioning is the German-language historical sciences' particular contribution to a different-but also qualitative-approach based on reported biographies to study historical change, namely, the oral-history approach (Niethammer, 1991). Moreover, some projects from the Bremen CRC 186 issued a strong plea for mixed-methods approaches to life-course analysis and successfully applied them (Kelle, 2008; Knappertsbusch/Langfeldt/Kelle, MIXED-METHODS AND MULTIMETHOD RESEARCH, this volume).

\section{Life-Course Research after the Turn of the Century}

It is very much to the credit of German-language life-course research that life-courserelated and biographical analyses are now part of the canon of empirical research in the German-language social sciences. In particular, studies on demographic behavior (Höpflinger, DEMOGRAPHY AND AGING, this volume), social inequality (Otte/Boehle/ Kunißen, SOCIAL INEQUALITIES-EMPIRICAL FOCUS, this volume), family (Konietzka/Feldhaus/Kreyenfeld/Trappe, FAMILY AND INTIMATE RELATIONSHIPS, this volume), labor-market participation (Aulenbacher/Grubner, WORK AND LABOR, this volume), happiness, and health usually follow a life-course perspective.

Conceptually and methodologically, the tradition of German-language life-course research made a difference in the international arena and continues to do so today. Literature published by Mayer and members of his group (cf. Mayer and Huinink, 1990) offered an idea of a comprehensive, interdisciplinary model of the life course as a complex behavioral process, an idea that has recently been reaffirmed by Bernardi, Huinink, and Settersten (2019). Their model conceives of the individual life course as the outcome of a nonlinear process driven by interdependencies in three dimensions: time (past, present, and future), life domains (e.g., work and family), and process 
levels (inner-individual, individual-behavioral, and supra-individual levels). These dimensions and the inherent interdependencies are themselves strongly dependent on each other. According to the authors, this model provides an adequate tool for analyzing all aspects of life-course dynamics and applies an interdisciplinary perspective that is assumed to be essential in advanced life-course research.

Kohli's approach initiated a growing body of life-course research that used the toolbox of biographical analysis. Hollstein took this further and not only showed how the analysis of qualitative, narrative-biographical interview data contributes to a deeper theoretical understanding of life-course dynamics and enriches theorybuilding but also how such data can be integrated into a mixed-methods procedure (Hollstein, 2019).

The Bremen Research Centre 186 fostered the idea of research focusing more attention on individual agency, cultural and institutional conditions of gendered life courses, and the significance of social policy among other factors, thereby advocating the concept of life-course policy (Heinz et al., 2009; Pfau-Effinger/Grages, SOCIAL POLICY, this volume).

Methodically, German life-course researchers did not merely have a prominent role in the development of event-history analytical methods (Blossfeld et al., 2007). They also contributed considerably to the progress made in quantitative life-course research that used panel methods of "causal” analysis (Brüderl, Kratz, and Bauer, 2019) and the more "descriptive" methods of sequence analysis (Fasang and Raab, 2014; Raab et al., 2014; Barth/Blasius, QUANTITATIVE METHODS, this volume). Additionally, German-speaking scholars made major contributions to qualitative and biographical life-course research, which we will describe in more detail in section four.

In parallel to the conceptual developments and the advances in life-course data analysis, the life-course perspective has heavily influenced data collection in Germanlanguage sociology, specifically in regard to the design of quantitative, micro-level empirical surveys. Collecting at least some retrospective data as an empirical basis for life-course related studies has since become an obligatory part of cross-sectional surveys. The notion of a strong interdependence between different dimensions of the life course (life domains) and, even more so, the interplay between subjective attitudes, norms, and dispositions with overt action and its consequences (selection and adaptation) gave rise to long-term panel surveys that would allow for the reliable measurement of changing subjective indicators over time (Huinink et al., 2011). Early on, socio-economic panel studies collected primarily objective indicators like income and employment, and the recording of social-status indicators started as far back as the 1970 s and 1980s in the U.S., Britain, and Germany. Since then, the questionnaires used by these panel surveys have come to include psychological indicators and subjective variables such as values, attitudes, and well-being.

In addition to the German Socio-Economic Panel (SOEP), which has already been running for 35 years (Goebel et al., 2019), new panels have been established within the last two decades. These follow a life-course perspective and allow researchers to 
combine information on the temporal development of objective and subjective indicators and study their mutual interdependence. Examples of major efforts in this regard are the German National Educational Panel Study (NEPS), which is primarily designed for educational research (Blossfeld and Roßbach, 2019); the German Family Panel (pairfam), which is primarily designed for family research (Huinink et al., 2011); and the German Twin Family Panel (TwinLife), which is primarily designed to illuminate how psychic and social resources mediate genetic and environmental contributions to individual development (Hahn et al., 2016). Many other panel studies that have emerged over the last two decades could also be mentioned (Höpflinger, DEMOGRAPHY AND AGING, this volume; Konietzka/Feldhaus/Kreyenfeld/Trappe, FAMILY AND INTIMATE RELATIONSHIPS, this volume; Otte/Boehle/Kunißen, SOCIAL INEQUALITIES-EMPIRICAL FOCUS, this volume); however, they are all exclusively surveys that collect standardized data. Qualitative panel data collection is still quite rare (Keupp et al., 2002; Dimbath, 2003; Schütze, 2015; Vogl and Zartler, 2020).

\section{The Main Fields of Life-Course Research in German-Language Sociology}

An overview of the main fields of German-language life-course research is perforce very selective. However, it is possible to identify various topics on which Germanlanguage research has traditionally focused and continues to pursue.

First among these is the transition to adulthood (Konietzka, 2010). For instance, recent findings on the age at which individuals leave home in Germany showed that, contrary to widely shared expectations, this age increased only slightly in birth cohorts during the first three decades after World War II following a period of a steady decline (cf. Konietzka and Tatjes, 2018). This corresponds to the finding that cohabitation replaced early marriage in these birth cohorts to a considerable extent. Consequently, the age at which individuals started living together with a partner also rose only moderately compared to their age at marriage (Konietzka, 2010).

Second, and related to this area of research, are studies on demographic and family change (i.e., family formation and dissolution) (e.g., Kreyenfeld, 2010; Kreyenfeld and Trappe, 2020; Wagner et al., 2019; Wagner et al., 2015; Konietzka/ Feldhaus/Kreyenfeld/Trappe, FAMILY AND INTIMATE RELATIONSHIPS, this volume). In particular, a major issue of interest has been the strong interdependence between family dynamics, education, and work and how it determines the options that are available to women to reconcile family and work (cf. Aisenbrey and Fasang, 2017; Blossfeld and Drobnič, 2001; Kühn, 2004).

A third field of research can be drawn from the plethora of studies that have analyzed the inter- and intragenerational dynamics of education, one's occupational career, class membership, and social inequality (cf. Blossfeld and Roßbach, 2019; Fasang and Mayer, 2020; Grundmann, EDUCATION AND SOCIALIZATION, this vol- 
ume). Some of these studies have revealed that the long-term upward trends in the mean educational and occupational status of German birth cohorts over the last century are far from being as stable as they have seemed to be. These studies have clearly determined the long-lasting impact of dramatic historical experiences on individual life courses (Becker and Blossfeld, 2017; Becker and Mayer, 2019). They have also found evidence of a weakening but still very strong transmission of social inequality from one generation to the next.

Fourth, and more recently, there has been a rapid expansion of research on spatial mobility over one's life course-mostly in relation to other life domains such as work, intimate partnerships, and family (cf. Huinink and Feldhaus, 2012; Kley, 2011; Wagner and Mulder, 2015). New findings from the analyses of job-related spatial mobility, for instance, have shown that long-distance commuting (albeit only for women) weakens the quality and stability of intimate partnerships. It also significantly delays family formation.

A fifth major field of life-course research in German-language sociology has dealt with living conditions and status transitions in later life (cf. Kohli and Künemund, 2005; Börsch-Supan, 2020; Höpflinger, DEMOGRAPHY AND AGING, this volume) and with intergenerational relationships (cf. Szydlik, 2016; Steinbach, 2012). These analyses have come to include more than just two familial generations, which has illuminated the role of grandparents and, for instance, shed new light on the "importance of the (grand-)paternal line in the intergenerational reproduction of relationship styles” (Hank et al., 2017: 134).

Sixth, international comparisons in regard to all areas of research mentioned here have yielded important insights into the logic of the societal conditions of life-course trajectories (cf. Mayer, 2004; Blossfeld, 2009). In the wake of German reunification, also studies on East German life courses-often in comparison to West Germany-have been conducted on many of these topics. They have shown the remarkable and enduring differences between East and West Germany. However, researchers have also observed rapid processes of assimilation with respect to the incidence and timing of major life-course transitions (cf. Diewald et al., 2006; Konietzka, 2010).

One can summarize this short overview by making three general observations. The first refers to whether the findings of this body of research support the assumption that the social change that has occurred over last five decades along with ongoing processes of globalization have led to a continuing de-standardization of life trajectories. To this there is no clear answer. In Germany at least, only moderate trends toward a destandardization of the life course have been identified thus far (cf. Mills and Blossfeld, 2003; Scherger, 2007; Kohli, 2007; Wagner and Cifuentes, 2014). The second observation is that empirical life-course research is recognizing the fact that processes in one domain of the life course cannot be analyzed adequately without accounting for the complex interdependence with many other life domains (cf. Aisenbrey and Fasang, 2017; Bernardi et al., 2019; Diewald, 2003). The third observation concerns the shift from retrospective data to panel data (cf. Brüderl et al., 2019). Analyses that use "objective" information on life events could easily be conducted using retrospective 
data (quantitative or qualitative) and attain reliable results largely through the use of event-history or sequence analysis. When long-term panel data became available, this expanded the opportunities for quantitative life-course analysis considerably. Now, studies can use the kinds of information that previously could not be collected reliably in retrospective surveys because of severe and systematic recall errors. For instance, the availability of panel data substantially advanced the possibilities of investigating the dynamics of individual life courses. Examples of such progress include studies on the interdependence of behavioral intention and overt behavior across life domains. In other words, the intention to, say, have a(nother) child has effects on an individual's likelihood to be residentially mobile, although this also depends on the social status of the actors (Vidal et al., 2017). Another example is the analyses of the changes in well-being or life satisfaction over time. Panel data also allow-at least to a certain extent-one to account for self-selectivity and to avoid biased estimates in analyses investigating the effects of life-course experiences (cf. Schmiedeberg et al., 2017).

\section{Biographical Analysis}

Elaborate quantitative analyses can shed light on the movement, pathways, and patterns of action of individuals and groups over time and the institutional structure of the life course. Qualitative methods help to further understand aspects of the life course as a multidimensional behavioral process as well as the driving forces behind individual life courses. Individual agency in particular, including how much and what type of agency is involved in shaping individual life courses, is a core interest addressed by biographical analysis. How do people link and balance different spheres of life, such as family obligations and their careers (i.e., interdependencies between life domains)? How do social networks affect individuals' biographical decisions (i.e., interdependencies between micro- and meso-levels) (cf. Bernardi et al., 2019)? How do past experiences influence current perceptions, orientations, and actions, and how do individuals organize biographical transitions? Do they draw on long-term plans, or are they just muddling through (i.e., time-related interdependencies) (ibid.)?

Biographical research with reconstructive methods offers an elaborate methodological approach to address these questions, yet it is only recently-decades after their development-that texts describing these methods have been translated into English (cf. Breckner, 2015; Hollstein, 2019). Occasionally, these approaches have been labeled as the "German school" in biographical research (Bertaux and Kohli, 1984; Apitzsch and Inowlocki, 2000), and they have taken root internationally in the International Sociological Association's Research Committee on Biography and Society (RC38) (Breckner, 2015; cf. also Miller, 2005; Harrison, 2009). These reconstructive, sequential analytical approaches (e.g., Schütze, 1976, 2008; Oevermann et al., 1987; Rosenthal, 1993; 2006; Nohl, 2010; Hollstein/Kumkar, QUALITATIVE METHODS, this volume) have dominated biographical research in German-speaking countries, which itself is a 
highly visible part of German-language sociology (cf. Lutz et al., 2018; Jost and Haas, 2019). ${ }^{1}$

In sequential analytical approaches, researchers interpret the interview data sequentially (word for word, line by line) and take into account differences between communicative schemes of representing one's life and perception of the world (i.e., text types)-especially with regard to whether the interviewee does so in the form of a narration, a description, or an argumentation-as well as consider the interaction between interviewer and interviewee (e.g., Schütze, 2008). These elaborate interpretative techniques can serve several purposes in life-course research that cannot be addressed equally by means of quantitative or other qualitative methods, such as semi-structured interviews. This is because the sequential analysis of autobiographical narrative interviews makes it possible to distinguish between reported and experienced life history and to reconstruct tacit knowledge and the orientations that guide an individual's actions, which are partly unintentional or even unconscious (Rosenthal, 2006; Schütze, 2008; Nohl, 2010). In particular, autobiographical extempore narrations offer unique avenues to understanding biographical decisionmaking and the layers of biographical experiences and planning, to investigating the question of how individuals link different spheres of life, and to exploring different types of agency (Schütze, 2008; Hollstein, 2019).

Of course, the methodological status of an extempore narration about a person's life course is a matter of some debate. Some researchers state that biographical accounts are mostly representations of the interviewee's "structured self-images," something that has little to do with social reality (cf. Kohli, 1981; Schütze, 2008). Pierre Bourdieu (1986) even spoke provocatively of a "biographical illusion.” Biographical researchers who work with sequential analysis would concede that autobiographical accounts do not simply mirror "social reality” (Rosenthal, 2006; Schütze, 2008). But they would also maintain that autobiographical extempore narrations in particular are neither fully invented, nor do they depend solely on external factors such as the interviewee's current situation. For example, by comparing passages from narrations with current interpretations documented in descriptive and argumentative parts of a biographical interview, the researcher is able to account for reinterpretations of experiences and events (Schütze, 2008: 171f.).

Reconstructive, sequential analytical methods (Hollstein/Kumkar, QUALITATIVE METHODS, this volume) have been used by several schools of biographical analysis: narration analysis as introduced by Fritz Schütze (2008), objective hermeneutics (Oevermann et al., 1987; Wernet, 2014), and the documentary method (Bohnsack, 2010, 2014; Nohl, 2010). For instance, by following Karl Mannheim and loosely referencing Bourdieu's habitus concept, Ralf Bohnsack has aimed to reconstruct the

1 For instance, in the German Sociological Association, the working group on biographical research was founded in 1979 and became a regular section in 1986, long before the section on qualitative methods was established in 2003. 
implicit (atheoretical, incorporated) knowledge of social actors and the orienting frames that guide their actions. This interest implies a change in analytical stance from asking what to asking how, from immanent or literal meaning to documentary meaning (Bohnsack, 2010): "It is the change from the question what social reality is in the perspective of actors, to the question how this reality is produced or accomplished in these actors' everyday practice" (ibid.: 102; italics in the original). By distinguishing between explicit knowledge (i.e., subjective representations) and tacit knowledge or action orientations, which are partly unconscious, these methods provide a means to reconstruct different types of agency, how people relate to external circumstances through their actions, and the degree of autonomy they experience. Furthermore, it is possible to account for the genesis of such agency, or rather, "how an individual develops certain ways of reacting to difficult situations and experiences in the past" (Breckner and Rupp, 2002: 299; cf. also Wohlrab-Sahr, 2006). In his own seminal studies, Schütze reconstructed four types of elementary "biographical process structures" (2008) and how they change over the life course. "Biographic action schemes" are characterized by a high degree of autonomy, whereas "institutional expectation patterns" characterize institutionally shaped and normatively defined courses, such as career trajectories within an organization. In "trajectories of suffering," people only react to overwhelming external events. "Transformations," by contrast, refer to individuals actively dealing with biographical events that did not turn out as originally planned. Such elementary process structures, especially institutional expectation patterns and trajectories of suffering, are of particular interest for life-course research since they represent quite weak types of agency (if any at all) that have not received much attention in prior studies (cf. Settersten and Gannon, 2005; Wohlrab-Sahr, 2002).

\section{Challenges Facing Life-Course Research in Germany (and Elsewhere)}

Even though life-course research has reached maturity, it still faces challenges that must be overcome if further desirable progress is to be made in understanding the interplay between the individual life course, or biographies, and social change. One could summarize that overcoming these challenges involves above all the integration of different methodological approaches in life-course research on the basis of a sound theoretical underpinning, as proposed, for instance, by Bernardi, Huinink, and Settersten (2019).

Such integration of quantitative and qualitative analysis in the study of life courses was one major aim of the CRC 186 in Bremen. However, it came to a standstill sometime during the last decade. Besides the Bremen studies, there are only a few other examples that combine life-course and biographical data in German-language sociology (e.g., Mayer and Schulze, 2009; Scherger and Vogel, 2018). And even though 
life-course research today accounts for large portions of empirical research in German sociology, it remains separated into two "camps," namely, a quantitative and qualitative one. We assume that this divide has deepened still further in recent decades. Institutional and cognitive hurdles to productive exchange seem to be higher than ever. On the one hand, this comes down to the increasing specialization of both biographical and life-course research, which has made exchange more difficult between the two. On the other hand, there has been what one might call a "constructivist turn" in biographical research. We do see a difference here with respect to the international literature, where both paradigms have been combined in a rather descriptive but very illuminating approach (e.g., Laub and Sampson, 2003). In this regard, we see great potential in research designs that engage quantitative life-course research and qualitative biographical research in an intelligent dialogue and integrate more refined studies of one kind or the other, such as the reconstructive biographical approaches that are more prominent in German-language sociology.

\section{References}

Aisenbrey, S.; Fasang, A. The Interplay of Work and Family Trajectories over the Life Course: Germany and the United States in Comparison. American Journal of Sociology 2017, 122, 1448-1484.

Apitzsch, U.; Inowlocki, L. Biographical analysis: a 'German' school? In The Turn to Biographical Methods in the Social Science; Chamberlayne, P.; Bornat, J.; Wengraf, T.; Eds; Routledge: London, 2000; pp 53-71.

Becker, R.; Blossfeld, H.-P. Entry of Men into the Labour Market in West Germany and their Career Mobility (1945-2008). A Long-term Longitudinal Analysis Identifying Cohort, Period, and Life-Course Effects. Journal of Labour Market Research 2017, 50, 113-130.

Becker, R.; Mayer, K. U. Societal Change and Educational Trajectories of Women and Men Born between 1919 and 1986 in (West) Germany. European Sociological Review 2019, 35, 147-168.

Bernardi, L.; Huinink, J.; Settersten Jr., R. A. The Life Course Cube: A Tool for Studying Lives. Advances in Life Course Research 2019, 41, 100258.

Bertaux, D.; Kohli, M. The Life Story Approach. A Continental View. Annual Review of Sociology 1984, 10, 215-237.

Blossfeld, H.-P. Kohortendifferenzierung und Karriereprozeß; Campus: Frankfurt a.M., 1989.

Blossfeld, H.-P. Comparative Life Course Research. A Cross-National and Longitudinal Perspective. In The Craft of Life Course Research; Elder, G. H.; Giele, J. Z., Eds; Guilford Press: New York, 2009; pp 280-306.

Blossfeld, H.-P.; Drobnič, S., Eds. Careers of Couples in Contemporary Society: From Male Breadwinner to Dual-Earner Families; Oxford University Press: Oxford, 2001.

Blossfeld, H.-P.; Hamerle, A.; Mayer, K. U. Event History Analysis: Statistical Theory and Application in the Social Sciences; Lawrence Erlbaum: Mahwah, NJ, 1989.

Blossfeld, H.-P.; Golsch, K.; Rohwer, G. Event History Analysis with Stata; Lawrence Erlbaum: Mahwah, NJ, 2007.

Blossfeld, H.-P.; Roßbach, H.-J., Eds. Education as a Lifelong Process. The German National Educational Panel Study (NEPS); Springer VS: Wiesbaden, 2019. 
Börsch-Supan, A. Life History Analyses with SHARE. In Handbook of Demographic Change and the Lifecourse; Falkingham, J.; Evandru, M.; Vlachatoni, A., Eds.; Edward Elgar: Cheltenham, 2020; pp 67-79.

Bohnsack, R. Documentary Method and Group Discussions. In Qualitative Analysis and Documentary Method in International Educational Research; Bohnsack, R.; Pfaff, N.; Weller, W., Eds.; Barbara Budrich: Opladen, 2010; pp 99-124.

Bohnsack, R. Documentary Method. In The Sage Handbook of Qualitative Data Analysis; Flick, U., Ed.; Sage: London, 2014; pp 217-234.

Bourdieu, P. L'illusion biographique. Actes de la recherche en sciences sociales 1986, 62/63, 69-72.

Breckner, R. The Biographical-Interpretative Method - Principles and Procedure. In Life Story Research, Volume III; Harrison, B., Ed.; Sage: Los Angeles, 2009; pp 137-164.

Breckner, R. Biography and Society. In International Encyclopedia of the Social and Behavioral Sciences, Volume 2, 2nd ed.; Wright, J. D., Ed.; Elsevier: Oxford, 2015; pp 537-643.

Breckner, R.; Rupp, S. Discovering Biographies in Changing Social Worlds. The Biographic Interpretive Method. In Experiences of Social Exclusion: Biography and Social Policy in Europe; Chamberlayne, P.; Rustin, M.; Wengraf, T., Eds.; Policy Press: London, 2002; pp 287-306.

Brückner, E.; Mayer. K. U. Collecting Life History Data. Experiences from the German Life History Study. In Methods of Life Course Research: Qualitative and Quantitative Approaches; Giele, J. Z.; Elder Jr., G. H., Eds.; Sage: Thousand Oaks, 1998; pp 152-181.

Brüderl, J.; Kratz, F.; Bauer, G. Life Course Research with Panel Data: An Analysis of the Reproduction of Social Inequality. Advances in Life Course Research 2019, 41, 100247.

Diewald, M. Kapital oder Kompensation? Erwerbsbiografien von Männern und die sozialen Beziehungen zu Verwandten und Freunden. Berliner Journal für Soziologie 2003, 13, 213-238.

Diewald, M.; Mayer, K. U. The Sociology of the Life Course and Life Span Psychology: Integrated Paradigm or Complementing Pathways? Advances in Life Course Research 2009, 14, 5-14.

Diewald, M.; Goedicke, A.; Mayer, K. U. After the Fall of the Wall: Life Courses in the Transformation of East Germany; Stanford University Press: Stanford, 2006.

Dimbath, O. Entscheidungen in der individualisierten Gesellschaft; Westdeutscher Verlag: Opladen, 2003.

Elder, G. H.; Giele, J. Z., Eds. The Craft of Life Course Research; Guilford Press: New York, 2009.

Fasang, A. E.; Mayer, K. U. Life Course and Social Inequality. In Handbook of Demographic Change and the Lifecourse; Falkingham, J.; Evandru, M.; Vlachatoni, A., Eds.; Edward Elgar: Cheltenham, 2020; pp 22-37.

Fasang, A. E.; Raab, M. Beyond Transmission: Intergenerational Patterns of Family Formation Among Middle-Class American Families. Demography 2014, 51, 1703-1728.

Goebel, J.; Grabka, M. M.; Liebig, S.; Kroh, M.; Richter, D.; Schröder, C.; Schupp, J. The German Socio-Economic Panel (SOEP). Journal of Economics and Statistics 2019, 239, 345-360.

Hahn, E.; Gottschling, J.; Bleidorn, W.; Kandler, C. What Drives the Development of Social Inequality Over the Life Course? The German TwinLife Study. Twin Research and Human Genetics 2016, 19, 659-672.

Hank, K.; Salzburger, V.; Silverstein, M. Intergenerational Transmission of Parent-Child Relationship Quality: Evidence From a Multi-Actor Survey. Social Science Research 2017, 67, 129-137.

Harrison, B., Ed. Life Story Research, 4 Volumes; Sage: Los Angeles, 2009.

Heinz, W. R. Self-Socialization and Post-Traditional Society. Advances in Life Course Research 2002, 7, 41-64.

Heinz, W. R. et al. CRC 186 Status Passages and Risks in the Life Course. Historical Social Research/Historische Sozialforschung 2001, 26, 256-267. 
Heinz, W. R.; Huinink, J.; Swader, C. S.; Weyman, A. Fundamental Conceptual Frameworks. General Introduction. In The Life Course Reader: Individuals and Society across Time; Heinz, W. R.; Huinink, J.; Weymann, A., Eds.; Campus: Frankfurt a.M., 2009; pp 15-30.

Hollstein, B. What Autobiographical Narratives Tell Us About the Life Course. Contributions of Qualitative Sequential Analytical Methods. Advances in Life Course Research 2019, 41, 100248.

Huinink, J. Warum noch Familie. Zur Attraktivität von Partnerschaft und Elternschaft in unserer Gesellschaft; Campus: Frankfurt a.M., 1995.

Huinink, J.; Mayer, K. U. u.a. Kollektiv und Eigensinn. Lebensverläufe in der DDR und danach; Akademie Verlag: Berlin, 1995.

Huinink, J.; Feldhaus, M. Family and Commuting Behaviour in Germany. Comparative Population Studies 2012, 37, 491-516.

Huinink, J.; Brüderl, J.; Nauck, B.; Walper, S.; Castiglioni, L.; Feldhaus, M. Panel Analysis of Intimate Relationships and Family Dynamics (pairfam) - Conceptual Framework and Design. Zeitschrift für Familienforschung/Journal of Family Research 2011, 23, 77-101.

Jost, G.; Haas, M., Eds. Handbuch zur soziologischen Biographieforschung; Barbara Budrich: Opladen, 2019.

Kelle, U. Die Integration qualitativer und quantitativer Methoden in der empirischen Sozialforschung; VS: Wiesbaden, 2008.

Keupp, H.; Ahbe, T.; Gmür, W.; Höfer, R.; Mitzscherlich, B.; Kraus, W.; Sraus, F. Identitätskonstruktionen. Das Patchwork der Identitäten in der Spätmoderne; Rowohlt: Reinbek near Hamburg, 2002.

Kley, S. Explaining the Stages of Migration within a Life-course Framework. European Sociological Review 2011, 27, 469-486.

Kohli, M. Soziologie des Lebenslaufs; Luchterhand: Darmstadt/Neuwied, 1978.

Kohli, M. Biography: Account, Text, Method. In Biography and Society; Bertaux, D., Ed.; Sage: Beverly Hills, 1981; pp 61-75.

Kohli, M. Institutionalisierung des Lebenslaufs. Historische Befunde und theoretische Argumente. Kölner Zeitschrift für Soziologie und Sozialpsychologie 1985, 37, 1-29.

Kohli, M. Normalbiographie und Individualität. Zur institutionellen Dynamik des gegenwärtigen Lebenslaufregimes. In Vom Ende des Individuums zur Individualität ohne Ende; Brose, H.-G.; Hildenbrand, B., Eds.; Leske + Budrich, 1988; pp 33-53.

Kohli, M. The Institutionalization of the Life Course: Looking Back to Look Ahead. Human Development 2007, 4, 253-271.

Kohli, M.; Künemund, H., Eds. Die zweite Lebenshälfte. Gesellschaftliche Lage und Partizipation im Spiegel des Alters-Survey; VS: Wiesbaden, 2005.

Konietzka, D. Zeiten des Übergangs. Sozialer Wandel des Übergangs in das Erwachsenenalter; VS: Wiesbaden, 2010.

Konietzka, D.; Tatjes, A. "Hotel Mama” revisited. Stabilität und Wandel des Auszugs aus dem Elternhaus im langfristigen Kohortenvergleich. Kölner Zeitschrift für Soziologie und Sozialpsychologie 2018, 70, 105-129.

Kreyenfeld, M. Uncertainties in Female Employment Careers and the Postponement of Parenthood in Germany. European Sociological Review 2010, 26, 351-366.

Kreyenfeld, M; Trappe, H., Eds. Parental Life Courses after Separation and Divorce in Europe; Springer Open: Cham, 2020.

Krüger, H.; Levy, R. Linking Life Courses, Work, and the Family: Theorizing a not so Visible Nexus between Women and Men. Canadian Journal of Sociology 2001, 26, 145-166.

Kühn, T. Berufsbiografie und Familiengründung. Biografiegestaltung junger Erwachsener nach Abschluss der Berufsausbildung; VS: Wiesbaden, 2004.

Laub, J. H.; Sampson, R. J. Shared Beginnings, Divergent Lives. Delinquent Boys to Age 70; Cambridge University Press: New York, 2003. 
Leisering, L. Government and the Life Course. In Handbook of the Life Course; Mortimer, J. T.; Shanahan, M. J., Eds.; Springer: New York, 2004; pp 205-225.

Leisering, L.; Leibfried, S. Time and Poverty in Western Welfare States. United Germany in Perspective; Cambridge University Press: Cambridge, 1999.

Lutz, H.; Schiebel, M.; Tuider, E., Eds. Handbuch Biographieforschung; Springer VS: Wiesbaden, 2018.

Mayer, K. U. Lebensverläufe und sozialer Wandel: Anmerkungen zu einem Forschungsprogramm. In Lebensverläufe und sozialer Wandel. Sonderheft 31 Kölner Zeitschrift für Soziologie und Sozialpsychologie; Mayer, K. U., Ed.; Westdeutscher Verlag: Opladen, 1990; pp 7-21.

Mayer, K. U. Whose Lives? How History, Societies, and Institutions Define and Shape Life Courses. Research in Human Development 2004, 1, 161-187.

Mayer, K. U. New Directions in Life Course Research. Annual Review of Sociology 2009, 35, 413-433.

Mayer, K. U.; Blossfeld, H.-P. Die gesellschaftliche Konstruktion sozialer Ungleichheit. In Lebenslagen, Lebensläufe, Lebensstile. Sonderband 7 Soziale Welt; Berger, P. A.; Hradil, S., Eds.; Schwartz: Göttingen, 1990; pp 297-318.

Mayer, K. U.; Huinink, J. Age, Period, and Cohort in the Study of the Life Course: A Comparison of Classical A-P-C-Analysis with Event History Analysis, or Farewell to Lexis? In Data Quality in Longitudinal Research; Magnusson, D.; Bergman, L. R., Eds.; Cambridge University Press: Cambridge, 1990; pp 211-232.

Mayer, K. U.; Müller, W. The State and the Structure of the Life Course. In Human Development and the Life Course; Sørensen, A. B.; Weinert, F. E.; Sherrod, L. R., Eds.; Lawrence Erlbaum: Hillsdale, NJ, 1986; pp 219-245.

Mayer, K. U.; Schulze, E. Die Wendegeneration. Lebensverläufe des Jahrgangs 1971; Campus: Frankfurt a.M., 2009.

Miller, R. L., Ed. Biographical Research Methods; Sage: London, 2005.

Mills, M.; Blossfeld, H.-P. Globalization, Uncertainty and Changes in Early Life Courses. Zeitschrift für Erziehungswissenschaft 2003, 6, 188-218.

Niethammer, L. Die volkseigene Erfahrung; Rowohlt: Berlin, 1991.

Nohl, A.-M. The Documentary Interpretation of Narrative Interviews. In Qualitative Analysis and Documentary Method in International Educational Research; Bohnsack, R.; Pfaff, N.; Weller, W., Eds; Barbara Budrich: Opladen/Farmington Hills, MI., 2010; pp 195-218.

Oevermann, U., Allert, T.; Konau, E.; Krambeck, J. Structures of Meaning and Objective Hermeneutics. In Modern German Sociology; Meja, V.; Misgeld, D.; Stehr, N., Ed.; Columbia University Press: New York, 1987; pp 436-447.

Raab, M.; Fasang, A.; Karhula, A.; Erola, J. Sibling Similarity in Family Formation. Demography 2014, 51, 2127-2154.

Rosenthal, G. Reconstruction of Life Stories Principles of Selection in Generating Stories for Narrative Biographical Interviews. The Narrative Study of Lives 1993, 1, 59-91.

Rosenthal, G. The Narrated Life Story: On the Interrelation Between Experience, Memory and Narration. In Narrative, Memory \& Knowledge: Representations, Aesthetics, Contexts; University of Huddersfield: Huddersfield, 2006; pp 1-116.

Scherger, S. Destandardisierung, Differenzierung, Individualisierung. Westdeutsche Lebensläufe im Wandel; VS: Wiesbaden, 2007.

Scherger, S.; Vogel, C., Eds. Arbeit im Alter. Zur Bedeutung bezahlter und unbezahlter Tätigkeiten in der Lebensphase Ruhestand; Springer VS: Wiesbaden, 2018.

Schmiedeberg, C.; Huyer-May, B.; Castiglioni, L.; Johnson, M. D. The More or the Better? How Sex Contributes to Life Satisfaction. Archives of Sexual Behavior 2017, 46, 465-473.

Schütze, F. Zur Hervorlockung und Analyse von Erzählungen thematisch relevanter Geschichten im Rahmen soziologischer Feldforschung - dargestellt an einem Projekt zur Erforschung 
kommunaler Machtstrukturen. In Kommunikative Sozialforschung; Arbeitsgruppe Bielefelder Soziologen, Eds.; Fink: Munich, 1976; pp 159-261.

Schütze, F. Biographieforschung und narratives Interview. Neue Praxis 1983, 13, 283-293.

Schütze, F. Biography Analysis on the Empirical Base of Autobiographical Narratives: How to Analyze Autobiographical Narrative Interviews - Part I and II. European Studies on Inequalities and Social Cohesion 2008, 1, 153-298 and 3, 6-77.

Schütze, Y. Twenty Years After. Netzwerke russisch-jüdischer Migranten im Zeitverlauf. BIOS 2015, 1 $+2,200-217$.

Settersten Jr., R. A.; Gannon, L. Structure, Agency, and the Space Between: On the Challenges and Contradictions of a Blended View of the Life Course. In Towards an Interdisciplinary Perspective on the Life Course; Levy, R.; Ghisletta, P.; LeGoff, J.-M.; Spini, D.; Widmer, E., Eds.; Elsevier: London, 2005; pp 37-57.

Steinbach, A. Intergenerational Relations Across the Life Course. Advances in Life Course Research 2012, 17, 93-99.

Szydlik, M. Sharing Lives - Adult Children and Parents; Routledge: London/New York, 2016.

Vidal, S.; Huinink, J.; Feldhaus, M. Fertility Intentions and Residential Relocations. Demography 2017, 54, 1305-1330.

Vogl, S.; Zartler, U. Interviewing Adolescents Through Time: Balancing Continuity and Flexibility in a Qualitative Longitudinal Study. In Longitudinal and Life Course Studies, 2020 (forthcoming).

Wagner, M.; Cifuentes, I. Die Pluralisierung der Lebensformen - ein fortlaufender Trend? Comparative Population Studies 2014, 39, 73-98.

Wagner, M.; Mulder, C. Spatial Mobility, Family Dynamics, and Housing Transitions. Kölner Zeitschrift für Soziologie und Sozialpsychologie 2015, 67, 111-135.

Wagner, M.; Schmid, L.; Weiß, B. Exploring Increasing Divorce Rates in West Germany: Can We Explain the Iron Law of Increasing Marriage Instability? European Sociological Review 2015, 31, 211-229.

Wagner, M.; Mulder, C.; Weiss, B.; Krapf, S. The Transition from Living Apart Together to a Coresidential Partnership. Advances in Life Course Research 2019, 39, 77-86.

Wernet, A. Hermeneutics and Objective Hermeneutics. In The Sage Handbook of Qualitative Data Analysis; Flick, U., Ed., Sage: London, 2014; pp 234-247.

Weymann, A. Interrelating Society and Biography. Discourses, Markets and the Welfare State's Life-Course Policy. In Society and Biography; Weymann, A.; Heinz, W. R., Eds.; Deutscher Studien Verlag: Weinheim, 1996; pp 241-258.

Weymann, A. Future of the Life Course. In Handbook of the Life Course; Mortimer, J. T.; Shanahan, M. J., Eds.; Springer: New York, 2004; pp 703-714.

Weymann, A.; Sackmann, R.; Wingens, M. Social Change and the Life Course in East Germany: A Cohort Approach to Inequalities. International Journal of Sociology and Social Policy 1999, 19, 90-114.

Wohlrab-Sahr, M. Prozessstrukturen, Lebenskonstruktionen, biographische Diskurse. Positionen im Feld soziologischer Biographieforschung und mögliche Anschlüsse nach außen. BIOS 2002, 15, 3-23.

Wohlrab-Sahr, M. Symbolizing Distance: Conversion to Islam in Germany and the United States. In Women Embracing Islam; van Nieuwkerk, K., Ed.; University of Texas Press: Austin, 2006; pp 71-92. 